\title{
Multi-Criterion Decision Model for Marina Location Selection in the County of Primorje and Gorski Kotar
}

\section{Primjena višekriterijske analize pri izboru lokacije za izgradnju marine u Primorsko-goranskoj županiji}

\author{
\begin{tabular}{l|l|l} 
Livia Maglić & Patricija Varaždinac & Ivona Škiljan \\
$\begin{array}{l}\text { University of Rijeka } \\
\text { Faculty of Maritime Studies }\end{array}$ & Rijeka & e-mail: patricijavarazdinac@gmail.com \\
$\begin{array}{l}\text { Rijeka } \\
\text { email: livia@pfri.hr }\end{array}$ & & e-mail: ivona_skiljan@hotmail.com \\
\end{tabular}
}

\begin{abstract}
Summary
The purpose of the research was to select the most suitable location for marina construction in the County of Primorje and Gorski Kotar, based on multi-criteria analysis. Potential locations for marina construtions are defined by the Spatial Plan of the County of Primorje and Gorski Kotar, and in this paper three locations are analyzed and evaluated: Rab, Kačjak (Dramalj) and Voz (Krk). The multi-criterion analysis is applied for the spatial evaluation of the location for marina construction in the County of Primorje and Gorski Kotar. Multi-criterion is being done, based on 5 criteria groups and 14 subcriteria, using the Promethee and Gaia method. An assessment of the criterion weights and evaluation was achieved by interviewing the group of experts. The model was developed in the Visual Promethee software. Using the Promethee and Gaia method location Rab was selected as the most suitable one.
\end{abstract}

\begin{abstract}
Sažetak
Svrha je ovog rada odabir najpogodnije lokacije za smještaj marine na području Primorskogoranske županije. Potencijalne lokacije za smještaj marina definirane su Prostornim planom Primorsko-goranske županije, a u ovom radu analiziraju se i vrednuju tri lokacije, a to su redom: Rab, Kačjak (Dramalj) i Voz (Krk). Za izbor najpogodnije lokacije za izgradnju marine primijenjena je metoda višekriterijske analize. Višekriterijska analiza provedena je na temelju 5 grupa kriterija i 14 podkriterija koristeći Promethee i Gaia metodu. Procjena važnosti pojedinog kriterija i njihovo vrednovanje dobiveno je metodom intervjuiranja grupe eksperata. Za izradu višekriterijske analize korišten je program Visual Promethee te je, primjenom Promethee i Gaia metode, kao najpogodnija lokacija za smještaj marine odabran otok Rab.
\end{abstract}

DOI 10.17818/NM/2019/1.4 UDK 627.2(497.5 RAB)

Preliminary communication / Prethodno priopćenje Paper accepted / Rukopis primljen: 11. 7. 2018.

\section{KEY WORDS}

marina

the County of Primorje and Gorski

Kotar

multi-criterion analysis

Promethee method

Gaia method

\section{KLJUČNE RIJEČI}

marina,

Primorsko-goranska županija

višekriterijska analiza

Promethee metoda

Gaia metoda

\section{INTRODUCTION / Uvod}

Nautical tourism is a form of tourism marked by the movement of tourists by sea or rivers, including their access to ports and marinas. It covers the infrastructure in the ports and marinas necessary for the docking of vessels. The starting point for the development and the most valuable part of nautical tourism in the Republic of Croatia is extraordinary natural potential that provides a high position on the nautical tourism market. Considering the income of this form of tourism, it is one of the fastest-growing form of tourism for the Republic of Croatia. The Republic of Croatia is a desirable destination for sailors, because of that, there is a bigger request for berths in the sea. The development of nautical tourism and the construction of nautical tourism ports is very important for the growth of local and regional development of the Republic of Croatia since Croatia abounds in marine and coastal resources, but the problem appears in achieving balance between the environment and potential areas for the construction of nautical ports. The increase in the number of nautical ports is of a great importance for the County of Primorje and Gorski Kotar, considering the number of nautical ports and the number of berths these ports have, because the need for berths exceeds the offer itself. Therefore, there is a need to explore new potential locations for the construction of the marinas, taking into consideration the economic and environmental benefits of such undertaking.

\section{ANALYSIS OF THE PRESENT STATE OF THE NAUTICAL TOURISM PORTS IN THE COUNTY OF PRIMORJE AND GORSKI KOTAR / Analiza postojećih luka nautičkog turizma u Primorsko- goranskoj županiji}

In the year 2017 a total of 140 ports of nautical tourism were registered in the Republic of Croatia, from which 70 are marinas and other 70 ports are other types of nautical ports [2].Table 1 shows that there are 26 ports of nautical tourism ports in the Primorsko-goranska County, from which 15 are marinas (including dry marinas) and other 11 are other types of nautical ports. 
Table 1 Ports of nautical tourism in the Republic of Croatia in year 2017

Tablica 1. Luke nautičkog turizma u Republici Hrvatskoj u 2017. godini

\begin{tabular}{|c|c|c|c|c|c|c|c|c|c|}
\hline & \multirow[b]{2}{*}{ Total } & \multirow[b]{2}{*}{ Anchorage } & \multirow[b]{2}{*}{ Mooring } & \multicolumn{5}{|c|}{ Marinas } & \multirow[b]{2}{*}{$\begin{array}{l}\text { Uncategorised } \\
\text { nautical ports }\end{array}$} \\
\hline & & & & $\begin{array}{c}\text { Dry } \\
\text { marina }\end{array}$ & $\begin{array}{l}\text { Marina 1st } \\
\text { category }\end{array}$ & $\begin{array}{c}\text { Marina } 2 \text { nd } \\
\text { category }\end{array}$ & $\begin{array}{c}\text { Marina } 3 d \\
\text { category }\end{array}$ & $\begin{array}{c}\text { Marina, categorised } \\
\text { and marked by } \\
\text { anchors }\end{array}$ & \\
\hline $\begin{array}{l}\text { Republic of } \\
\text { Croatia }\end{array}$ & 140 & 61 & 6 & 13 & 5 & 16 & 17 & 19 & 3 \\
\hline $\begin{array}{l}\text { County of } \\
\text { Primorje and } \\
\text { Gorski Kotar }\end{array}$ & 26 & 9 & 2 & 5 & 1 & 2 & 3 & 4 & - \\
\hline
\end{tabular}

Source: Prepared by authors according to data from the Croatian Bureau of Statistics official website

Table 2 Capacity of the nautical tourism ports in the Republic of Croatia and in the County of Primorje and Gorski Kotar in year 2017 Tablica 2. Kapacitet luka nautičkog turizma u Republici Hrvatskoj i u Primorsko-goranskoj županiji u 2017. godini

\begin{tabular}{|c|c|c|c|}
\hline & Republic of Croatia & $\begin{array}{c}\text { County of Primorje and Gorski } \\
\text { Kotar }\end{array}$ & $\begin{array}{c}\text { \% share of the County of } \\
\text { Primorje and Gorski Kotar in the } \\
\text { Republic of Croatia }\end{array}$ \\
\hline Water surface area, $m^{2}$ & 3711951 & 623560 & 16,80 \\
\hline Moorings, total & 17067 & 2870 & 16,82 \\
\hline Number of berths for land storage & 4610 & 1398 & 30,33 \\
\hline Total surface area on land, $m^{2}$ & 741681 & 142326 & 19,19 \\
\hline
\end{tabular}

Source: Prepared by authors according to data from the Croatian Bureau of Statistics official website

According the Croatian Bureau of Statistics the total surface of port basin in the County of Primorje and Gorski Kotar is $623.560 \mathrm{~m} 2$, which is $16.80 \%$ of the total surface of port basin of the Republic of Croatia, and the number of berths is 2870 which is $16.82 \%$ of the total number of berths in the Republic of Croatiain year 2017 (Table 2).

In the ports of nautical tourism in the Republic of Croatia in 2017 there were 13433 vessels on a permanent berth, 11 641 were used berth in the sea, and 1792 vessels used berth on land. In the County of Primorje and Gorski Kotar, there were 2648 vessels on a permanent berth, 1895 vessels were used berth in the sea, and 753 vessels used berth on land, which is $19.71 \%$ of total number of vessels on a permanent berth in the Republic of Croatia [3]. Total number of vessels in transit in the Republic of Croatia is 201896,199623 were used berth in the sea, and 2273 vessels used berth on land. In the County of Primorje and Gorski Kotar, there were 21138 vessels in transit, 20993 used berth in the sea and 145 vessels used berth on land, which is $10,47 \%$ of total number of vessels in transit in the Republic of Croatia [3] (Figure 1).
In year 2017, the total income from the nautical ports in the Republic of Croatia was 855 million HRK [2]. Realized income from renting the berths was 598 milion HRK which is $70.0 \%$ from total income of nautical ports[3].Compared to 2016, total income was $11.2 \%$ higher, and rental income for $10.9 \%$. In year 2017 total income for the Primorsko-goranska County amounted to HRK 124 million, which is an increase, compared to 2016 by $18 \%$ (Table 3). From rented berths realized income was 97 million, which is an increase of $28 \%$ compared to 2016 (Table 3). Realized income from the permanent berths increased by $31 \%$ compared to 2016 [3].Accordingly, the share of the Primorsko Goranska County in 2016 in total income was $13.20 \%$. The share of rental income was $12.94 \%$, while the share in other revenues was $15.45 \%$. In 2017 , the share of the Primorsko Goranska County compared to the Republic of Croatia, increased by $14.50 \%$ in total income, $16.23 \%$ in income of renting of moorings and $18.26 \%$ of income in stationed, while share in transit and maintenance service decreased from $8.97 \%$ to $8,80 \%$ apropos $9.17 \%$ to $9.10 \%$, and the share in other revenues from $15.45 \%$ to $10.97 \%$.

\section{Vessels permanently berth in 2017.}

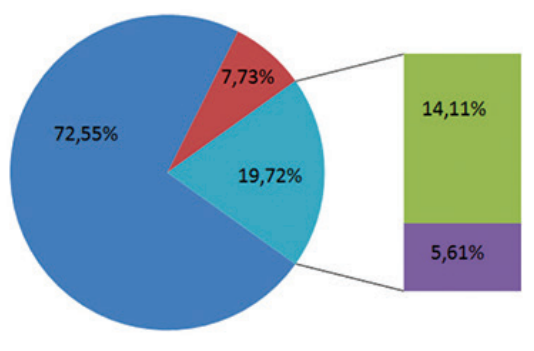

\section{Vessels in transit in 2017.}

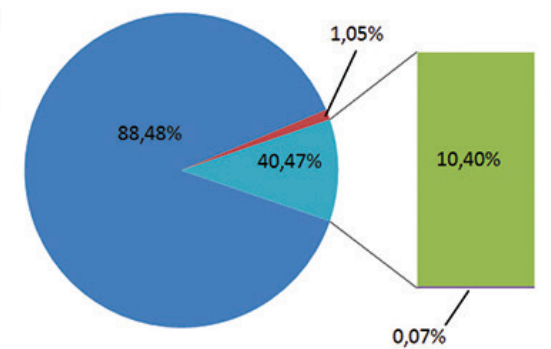

Figure 1 Share of vessels on a permanent and on a transit berth in the Republic of Croatia and the County of Primorje and Gorski Kotar in year 2017

Grafikon 1. Udio plovila na stalnom i tranzitnom vezu u Republici Hrvatskoj i Primorsko-goranskoj županiji u 2017. godini 
Table 3 Comparative analysis of realized income of the nautical tourism port in the County of Primorje and Gorski Kotar in year 2016. and 2017 (without VAT)

Tablica 3. Komparativna analiza poslovanja luka nautičkog turizma u Primorsko-goranskoj županiji u 2016. i 2017. godini (bez PDV-a)

\begin{tabular}{|c|c|c|c|c|c|c|}
\hline & $\begin{array}{l}\text { Republic of } \\
\text { Croatia } 2016\end{array}$ & $\begin{array}{l}\text { Republic of } \\
\text { Croatia } 2017\end{array}$ & $\begin{array}{c}\text { County of } \\
\text { Primorje and } \\
\text { Gorski Kotar } 2016\end{array}$ & $\begin{array}{c}\text { County of } \\
\text { Primorje and } \\
\text { Gorski Kotar } 2017\end{array}$ & $\begin{array}{l}\text { The share of the County } \\
\text { of Primorje and Gorski } \\
\text { Kotar in the Republic of } \\
\text { Croatia } 2016\end{array}$ & $\begin{array}{l}\text { The share of County } \\
\text { of Primorje and Gorski } \\
\text { Kotar in the Republic } \\
\text { of Croatia } 2017\end{array}$ \\
\hline Total income & 768938 & 855166 & 101482 & 124018 & 13,20 & 14,50 \\
\hline $\begin{array}{l}\text { Renting of } \\
\text { moorings }\end{array}$ & 539210 & 598191 & 69773 & 97069 & 12,94 & 16,23 \\
\hline Stationed & 422755 & 469601 & 59325 & 85748 & 14,03 & 18,26 \\
\hline In transit & 116455 & 128590 & 10448 & 11321 & 8,97 & 8,80 \\
\hline $\begin{array}{l}\text { Maintaining } \\
\text { services }\end{array}$ & 60202 & 65862 & 5523 & 5993 & 9,17 & 9,10 \\
\hline Other income & 169526 & 191113 & 26186 & 20956 & 15,45 & 10,97 \\
\hline
\end{tabular}

Source: Prepared by authors according to data from the Croatian Bureau of Statistics official website

The development of nautical tourism is important for the development of the Primorsko-goranska County. Along with existing marinas, there are exceptional spatial potentials as well as the need to form new marinas to create recognizable nautical destinations, taking into consideration its function and socioeconomic organization and ecological conditions [15]. In the Primorsko-goranska County there are ten marinas, capacity of nearly 2876 berths, and 19 extra marinas is planned with capacity over 5000 berths [11]. Apart from the formation of nautical moorings in ports for special purposes, capacity can also be achived by formation of nautical parts in the ports open for public. By Law on Spatial planning and construction it is enabled to form more nautical moorings in front of certain building areas for tourist purpose. Table 4 shows existing and planned marinas with capacitiy in the Primorsko-goranska County.

From Table 4 it is clear that according to the Spatial plan and Strategy of the Primorsko-goranska County 8 locations are planned for marinas construction with a total capacity of 2700 beths. Within existing and planned locations there are 19

Table 4 Existing, planned and potential locations for marinas construction in the County of Primorje and Gorski Kotar Tablica 4. Postojeće, planirane i potencijalne lokacije za izgradnju marina u Primorsko-goranskoj županiji

\begin{tabular}{|c|c|c|c|c|}
\hline Existing marinas & $\begin{array}{l}\text { Maximum } \\
\text { number of } \\
\text { berths }\end{array}$ & $\begin{array}{l}\text { Planned marinas } \\
\text { (Spatial plan of the County of } \\
\text { Primorje and Gorski Kotar and } \\
\text { Development of the Nautical } \\
\text { Tourism in the County of Primorje } \\
\text { and Gorski Kotar 2012.) }\end{array}$ & $\begin{array}{l}\text { Maximum } \\
\text { number of } \\
\text { berths }\end{array}$ & $\begin{array}{l}\text { Potential locations for marinas } \\
\text { construction } \\
\text { (Development possibilities of the } \\
\text { nautical ports in the County of } \\
\text { Primorje and Gorski Kotar, 2012.) }\end{array}$ \\
\hline Admiral - Opatija & 160 & Lovran & 200 & Opatijska luka \\
\hline lčići & 281 & Rijeka & 400 & Preluka \\
\hline Punat & 850 & Bakar & 300 & Kantrida \\
\hline Cres & 461 & Crikvenica & 200 & Brajdica \\
\hline Privlaka - Mali Lošinj & 70 & Krk & 400 & Baroš (Rijeka) \\
\hline Rab & 142 & Stara Baška & 400 & Škver Akademija \\
\hline Supetarska Draga & 328 & Nerezine & 400 & Perilo \\
\hline Novi Vinodolski & 204 & Mali Lošinj & 400 & Kačjak, Dramalj \\
\hline $\begin{array}{l}\text { Novi Vinodolski - } \\
\text { Muroskva }\end{array}$ & 180 & & & Otok Krk, cove Zala \\
\hline \multirow[t]{10}{*}{ Omišalj } & 200 & & & Otok Krk, Luka Omišalj \\
\hline & & & & Otok Mali Lošinj, cove Torunza \\
\hline & & & & Otok Cres, cove UI \\
\hline & & & & Otok Krk, Voz \\
\hline & & & & Otok Krk, Klimno \\
\hline & & & & Otok llovik i sv.Petar, canal Sv. Petar \\
\hline & & & & Otok Rab, Kampor \\
\hline & & & & Otok Grgur, sv.Grgur \\
\hline & & & & $\begin{array}{l}\text { Osor, along the mainland of island of } \\
\text { Lošinj }\end{array}$ \\
\hline & & & & Grad Rijeka, area along the city shore \\
\hline TOTAL & 2876 & TOTAL & 2700 & \\
\hline
\end{tabular}

Source: Prepared by the authors according to the Department for Physical Planning of the County of Primorje and Gorski Kotar official website 
potential locations for marinas construction in the County of Primorje and Gorski Kotar

\section{POTENTIAL LOCATIONS FOR MARINAS CONSTRUCTION IN THE COUNTY OF PRIMORJE AND GORSKI KOTAR / Potencijalne lokacije za izgradnju marina u Primorsko-goranskoj županiji}

The choice of the marinas location is the basic investment decision. The cost of building a marine, with a certain capacity and quality, depends on the features of the region. If the natural features of the region are more suitable the construction of the marina will be cheaper. Appropiate location selection ensures lower construction costs, better capacity utilization, higher sales prices for nautical-tourist services and higher profitability of invested capital. When planning an optimal location for marine construction, the underlying problem lies in the inconsistency of plans with development possibilities. In addition, the problem is the lack of spatial plans resulting in inadequate solutions in space. This problem is more significant when more than one marina is built on a relatively small and overcrowded space, and their construction is lacking at more convenient and cheaper locations. Each choice of marine location requires its adaptation to local urban plans and spatial plans for future development of the area. The positive effects of the construction of the marina are manifested at the overall level of tourism, and in particular through a range of activities such as sales, restaurant services, hotel and other accommodation services, rental of boats, services, etc. All this encourages the growth of local population income and the increase in the number of employees, and at the end result is an increase in the standard of living of the population. Apart from the benefits, the marina also has negative environmental impacts. The biggest problem that arises in the construction of a marine is pollution of the environment. This is caused by the discharge of black water from ships, the discharge of oil waste from the service, inadequate disposal of waste materials, etc. The other negative effects of marinas are: loss of habitats due to concreting, sea level change, sea pollution, increased noise levels, reduced light penetration which has negative consequences on plant communities.

The County of Primorje and Gorski Kotar is located in the northernmost part of the Croatian Adriatic and it represents the center of the Central European and Adriatic - Mediterranean directions. The surface area of the County of Primorje and Gorski Kotar is $7.994 \mathrm{~km}$, of which $3.595 \mathrm{~km}^{2}(45 \%)$ on the mainland and $3.99 \mathrm{~km}^{2}(55 \%)$ of the seas. The length of the coastal area of the County of Primorje and Gorski Kotar is 1,065 km [9]. The island area consists of Krk, Cres, Lošinj and Rab as big islands, and numerous small islands scattered around them.

According to the Nautical Tourism Development Strategy of the Republic of Croatia for the period 2009-2019, the current number of berths should be increased at various locations in the County. There are currently ten marinas in the County: Opatija, Ičići, Punat, Cres, Mali Lošinj, Supetarska Draga, Rab, Novi Vinodolski, Novi Vinodolski - Muroskva, Omišalj). In addition, there are plans to build another eight marinas in the areas of Lovran, Rijeka, Bakar, Crikvenica, Krk, Stara Baška, Nerezine and Mali Lošinj (Figure 1). In addition to the before mentioned marinas, nine potential locations for the construction of the marina were suggested in the studyDevelopment possibilities of the nautical ports in the Primorsko-goranska Countyand some of which are Kantrida, Brajdica, Perilo, Škver Akademija, Baroš, Kačjak and many other locations on the islands (Figure 2)[9].

This paper focuses on three locations, the Voz Bay (Krk), Kačjak (Dramalj) as potential locations and the ACI marina Rab as existing one (Figure 2). Mentioned locations are selected because with existing ACI marina Rab, potential locations Voz and Kačjak could also be seasonal character marinas, with approximately equal number and structure of the berths in the sea.

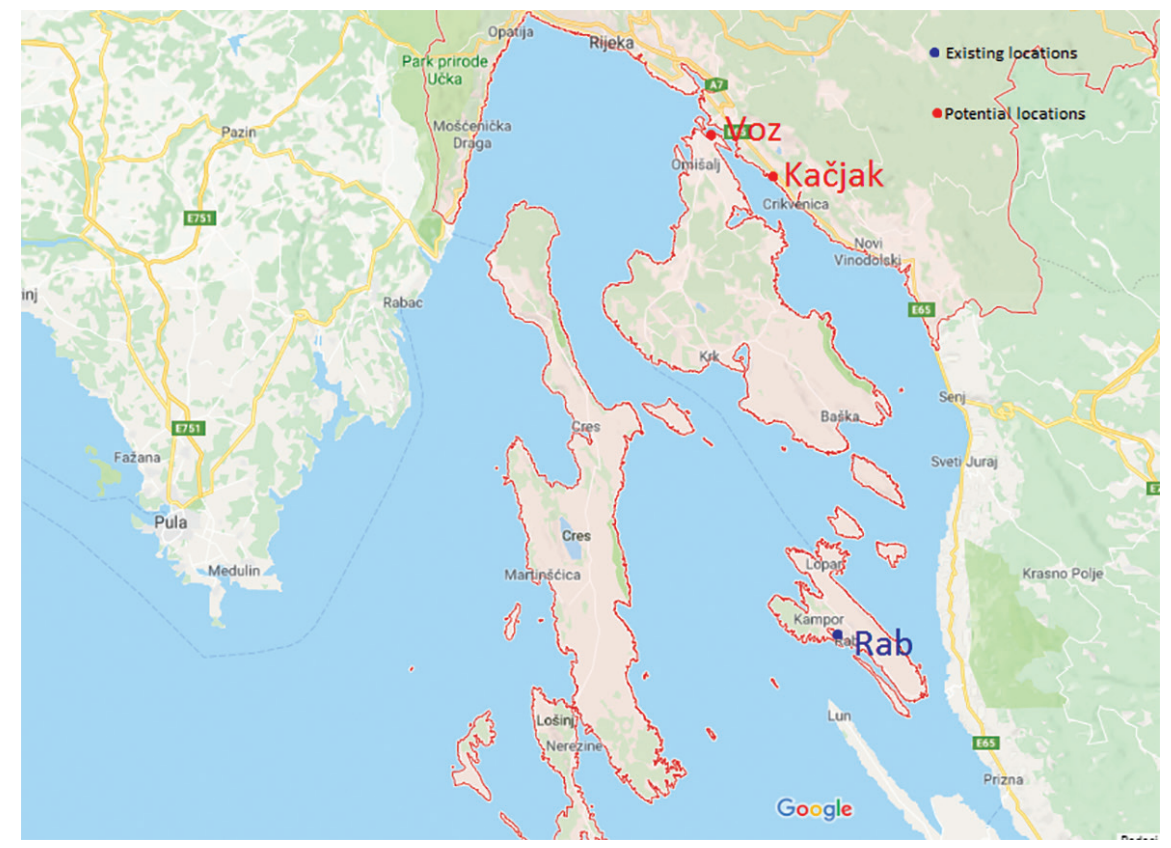

Figure 2. Selected locations for a multi-criterion decision model

Slika 2. Odabrane lokacije za izradu modela višekriterijske analize 
Voz is located on the northernmost part of the Island of Krk. In the proximity is the islet of Saint Marco. In exceptional circumstances, less waves can occur in the cove from the northwest during short-term summer dusk or winter tramuntane strikes. The slopes of the bay are sandy as well as underwater. The north coast is poorly covered with vegetation and it is rocky. The area is connected by road to the road system of the island of Krk. The mooring of the vessel would be possible on three floating single-lane gates of $40 \mathrm{~m}$ long, whose position would be on the northeast side of the bay to ensure the protection of the waves. The basic facilities of the marina would be constructed with gates with a minimum capacity of 60 berths, while additional facilities would be used in Omišalj [9]. The light winds from 1-3 Bf are prevailing, which represent $82 \%$ per annum, while orbital winds of $6 \mathrm{Bf}$ and more occur on average 25 days a year [14].

The mooring of Kačjak is located about 1.8 miles from Cape Ertak. It is characteristic because of the prominent pebble slope of the opaque color on the Cape of Kačjak and the building of a hotel resort. The bay is poorly protected but has a couple of berths. On the north of Cape Kacjak along the shore of the hotel resort there is a berth for hotel guests.

$\mathrm{ACl}$ marina Rab is located in the city's harbour, and offers plenty of facilities for the sailors - from restaurants to service workshops. The interior of the island is as impressive as the shore. Namely, 35\% of its surface is covered with forest and fertile land, so Rab today, after Mljet, is the second greenest island in Croatia.The average annual air temperature in the town of Rab is $15.1{ }^{\circ} \mathrm{C}$ [4]. The coldest month is January with an average temperature of $7.4^{\circ} \mathrm{C}$, and the warmest July with $24.3^{\circ} \mathrm{C}$ [4]. Relatively high winter temperature the city of Rab has due to the influence of the sea that prevents the air cooling in winter. In the summer the sea has an opposite, refreshing effect. The city of Rab has average of 8 cold days per year, with the lowest air temperature falling below $0{ }^{\circ} \mathrm{C}$ and up to 2-3 days in January and February. In July and August almost all days are warm, maximum air temperature exceeds $25^{\circ} \mathrm{C}$, and in $50 \%$ of that period the maximum daily temperature exceeds $30^{\circ} \mathrm{C}$ (hot days) and nighttime does not fall below $20^{\circ} \mathrm{C}$ (hot nights) [4].

The $\mathrm{ACl}$ marina is exposed to the southern winds, and particularlydangerous is the wind that creates high waves by switching them over the pier and sometimes, especially in the winter months, can cause boat junctions and even pontoon couplings. During the strong southern winds, a large puddle is created in the marina, and the sea level rises up to $0.8 \mathrm{~m}$, resulting in the fluttering of the western shore from the harbor to the end of the harbor [4].

\section{MULTI - CRITERION DECISION MODEL FOR MOST SUITABLE MARINA LOCATION SELECTION / Višekriterijska analiza pri izboru najpogodnije lokacije za smještaj marine}

To optimize the choice of a location, it is necessary to use the multi-criteria analysis and certain methods. The methods that can be used are the AHP method, PROMETHEE and GAIA methods [1]. The AHP method enables the comparison of the criteria and location in pairs and makes various analyses, such as the sensitivity analysis and some others. The GAIA program gives a geometric presentation of the results of PROMETHEE methods and can obtain numerical results and graphs that help the decision-maker to have a more realistic view of the problem[1].The PROMETHEE method was used in the choice of the most convenient location for marine construction. This method was developed with the intent to help solve the problem of multi-criteria decision making. The PROMETHEE method makes a comparison and ranking different alternatives that are simultaneously evaluated on the basis of more quantitative and qualitative criteria. Based on the PROMETHEE method, by comparing different criteria, the most suitable location for marina construction is obtained. Defining criteria is the first step in selecting a software tool for selecting and evaluating a location for a marina build. When setting criteria, spatial plans are of particular importance because they contain precise and detailed preparation of conditions for all location options. An important step in building a marina is choosing the location. Locations should be analyzed and taken into consideration the criteria to be evaluated and based on them, to choose the most suitable location. The criteria chosen for this analysis are divided into groups, so there are natural factors, socio - economic, traffic - technical, environmental, and nautical factors. In the proposed model for ACI marina Rab it is planned to increase existing capacity from total of 142 berths to 200 berths in the sea, while for other two locations the plan is construction of marina. The same set of criteria and sub-criteria are graded for each of these locations (Table 5). The importance of the criterion group and the sub-criteria rating were defined and based on an interviews of the group of experts.

In the planning of marinas, natural factors play a very important role. Natural factors include the influence of wind, the influence of waves and the sea temperature.The wind has a major impact on the safety of the marina, which is why its role can be crucial in deciding on planning and designing the marina [8]. Each of the observed locations differs in terms of wind blowing and wind strength. Therefore, ratings are awarded, one rating indicates very low, or wind blowing less than 1 Beaufort, while four grades signify a strong wind force over 5 Beauforts. According to the analysis of location Voz as a well-protected location of the bora and the souther, it is estimated as a weak wind while Kačjak and Rab as a moderately strong wind.After the wind, another important factor to consider while designing is the impact of the waves. The wave impact criterion is evaluated in terms of the Douglas Scale. The influence of the waves is evaluated by the height of the waves that appear, Grade 1 represents a calm sea with a wave height of $0-0.1 \mathrm{~m}$, while the grade 4 is strongly wavy with waves of $2.5-4 \mathrm{~m}$ and is minimized [2]. According to the analysis location Kačjak was evaluated wavy, while Rab and Voz slightly wavy. The data were obtained on the basis of the ACI Marina Rab and the Environmental Impact Study for the aforementioned locations. The Adriatic Sea has a very pronounced annual change in surface sea temperature. The average annual temperature is $11^{\circ} \mathrm{C}$ [2].The sea is coldest during the winter and the surface temperature of the sea is about $7^{\circ} \mathrm{Cand}$ it can rarely fall lower. In the spring sea becomes warmer so the surface temperature rises to $18^{\circ} \mathrm{C}$. In the summer sea temperature of the sea is high, even $22-25^{\circ} \mathrm{C}$ [2]. According to this data, the high seawater temperature is indicated in selected locations. The data were obtained on the basis of available data on the National Hydrometeorological Institute website.

The second group of factors are nautical factors which include the depth of the sea and the safety of the approach. Nautical criteria are especially valued when choosing a marine location. The 
Table 5 Criterion, sub-criterion and ratings for location evaluation

Tablica 5. Kriteriji, podkriteriji i ocjenske skale za evaluaciju lokacija

\begin{tabular}{|c|c|c|c|c|c|}
\hline CRITERION & SUB - CRITERION & RATINGS & ACI marina Rab & Voz, Krk & Kačjak, Dramalj \\
\hline \multirow{3}{*}{$\begin{array}{l}\text { NATURAL } \\
\text { FACTORS }\end{array}$} & The impact of wind & $\begin{array}{c}\text { Very weak - } 1 \\
\text { Weak }-2 \\
\text { Moderately strong - } 3 \\
\text { Strong - } 4\end{array}$ & $\begin{array}{c}\text { Moderately strong } \\
-3\end{array}$ & Weak - 2 & $\begin{array}{l}\text { Moderately } \\
\text { strong - } 3\end{array}$ \\
\hline & The impact of waves & $\begin{array}{c}\text { Quiet- } 1 \\
\text { Slightly wavy - } 2 \\
\text { Wavy - } 3 \\
\text { Strongly wavy - } 4\end{array}$ & Slightly wavy - 2 & Slightly wavy - 2 & Wavy - 3 \\
\hline & Sea temperature & $\begin{array}{l}\text { Low - } 1 \\
\text { Medium - } 2 \\
\text { High - } 3\end{array}$ & High - 3 & High - 3 & High - 3 \\
\hline \multirow[b]{2}{*}{ NAUTICAL FACTORS } & Depth of the sea & $\begin{array}{l}\text { Insufficient - } 1 \\
\text { Sufficient - } 2\end{array}$ & Sufficient - 2 & Sufficient - 2 & Insufficient - 1 \\
\hline & Safety approach & $\begin{array}{c}\text { Bad - } 1 \\
\text { Good - } 2 \\
\text { Ideally - } 3\end{array}$ & Ideally - 3 & Good - 2 & Good - 2 \\
\hline \multirow{5}{*}{$\begin{array}{c}\text { TRAFFIC - TEHNICAL } \\
\text { FACTORS }\end{array}$} & Number of berths & $\begin{array}{l}\text { Insufficient - } 1 \\
\text { Sufficient - } 2\end{array}$ & Sufficient - 2 & Sufficient - 2 & Sufficient - 2 \\
\hline & $\begin{array}{l}\text { The categorization of } \\
\text { marinas }\end{array}$ & $\begin{array}{l}\text { Two anchors - } 1 \\
\text { Three anchors - } 2 \\
\text { Four anchors - } 3 \\
\text { Five anchors - } 4\end{array}$ & Four anchors - 3 & Two anchors - 1 & Two anchors - 1 \\
\hline & $\begin{array}{c}\text { The proximity of the } \\
\text { city cores }\end{array}$ & $\begin{array}{l}\text { Very weak - } 1 \\
\text { Weak - } 2 \\
\text { Medium - } 3 \\
\text { High - } 4 \\
\text { Very high - } 5\end{array}$ & Very high - 5 & High -4 & High -4 \\
\hline & $\begin{array}{c}\text { The construction of } \\
\text { infrastructure }\end{array}$ & $\begin{array}{l}\text { Poor - } 1 \\
\text { Good - } 2 \\
\text { Ideally - } 3\end{array}$ & Ideally - 3 & Poor - 1 & Good - 2 \\
\hline & $\begin{array}{c}\text { The offer of } \\
\text { additional contents }\end{array}$ & $\begin{array}{l}\text { Very weak - } 1 \\
\text { Weak - } 2 \\
\text { Medium - } 3 \\
\text { High }-4 \\
\text { Very high - } 5\end{array}$ & Very high - 5 & Very weak - 1 & Weak - 2 \\
\hline \multirow{2}{*}{$\begin{array}{l}\text { ENVIRONMENTAL } \\
\text { FACTORS }\end{array}$} & $\begin{array}{c}\text { Ecological value of } \\
\text { micro - location }\end{array}$ & $\begin{array}{l}\text { Low importance }-1 \\
\text { Medium importance }-2 \\
\quad \text { Important }-3 \\
\text { Extremely important - } 4\end{array}$ & $\begin{array}{c}\text { Extremely } \\
\text { important - } 4\end{array}$ & Important - 3 & Important - 3 \\
\hline & The quality of the sea & $\begin{array}{l}\text { Unsatisfying - } 1 \\
\text { Satisfying - } 2 \\
\text { Good - } 3 \\
\text { Excellent - } 4\end{array}$ & Excellent - 4 & Excellent - 4 & Excellent - 4 \\
\hline \multirow{2}{*}{$\begin{array}{c}\text { SOCIO - ECONOMIC } \\
\text { FACTORS }\end{array}$} & $\begin{array}{c}\text { Attractiveness of the } \\
\text { location }\end{array}$ & $\begin{array}{c}\text { Low - } 1 \\
\text { Medium - } 2 \\
\text { High - } 3\end{array}$ & High - 3 & Low - 1 & Medium - 2 \\
\hline & $\begin{array}{c}\text { Price of the boat per } \\
\text { meter }\end{array}$ & $\begin{array}{l}\text { Low - } 1 \\
\text { Medium - } 2 \\
\text { High - } 3\end{array}$ & High - 3 & Low - 1 & Low - 1 \\
\hline
\end{tabular}

Source: Created by authors

depth of the sea determines the size of the boat and the minimum requirement for building a marine is the depth of water between 2 and 6 meters [7].Each of the observed locations differs depending on the depth of the sea. The lowest rating indicates the inadequate depth of the sea and the highest satisfactory depth. Based on the results obtained, the location of Kačjak was rated inadequately, while Rab and Voz were sufficiently deep.The criterion of safety approach is rated by grades 1-3 and it is minimized. The lowest rating is 1 and is a poor safety approach while the highest rating 3 represents the ideal safety approach. Location Rab is rated as ideal, while Kačjak and Voz have good safety approach.

The category of traffic-technical factors includes the number of berths, the categorization of marinas, the proximity of city cores, the infrastructure construction, and the offer of additional contents. These factors can have many advantages in building a marina, because of the existing infrastructure that contributes to the reduction of total costs in the project.Each of the observed locations differs depending on the number of berths. Accordingly, ratings were awarded, rating one for insufficient number of berths and rating two for a sufficient number of berths. According to the results, all three locations are rated with a sufficient number of berths.

The categorization of marinas is defined by anchors (their number) in the Ordinance on Classification and Categorization of Nautical Tourism Ports. Two anchors belong to the 4th category marinas, three anchors to the 3rd category marinas, four anchors to te 2 nd category marinas and five anchors to the marinas of $1 \mathrm{st}$ category. Due to the equipment of the marina and the offered 
contents, location Rab has four anchors, while Kačjak and Voz have two anchors.

Ratings for the proximity of the city cores are divided by the distance in kilometers from 1 to 5 . The rating one defines very poor proximity of the city cores and the rating five is very close proximity. Location Rab is rated very high while Voz and Kačjak are rated high.

Under the infrastructure of the area there are objects located below and above the surface of the land in its area, ie facilities of communal and nautical tourism services. Under poor construction with rating 1 were rated marinas that don't have necessary facilities at all, with rating 2 marinas which have infrastructure facilities and infrastructure network while rating 3 is rated where everything was previously respected and planned and utilized. Location Rab is rated as ideal, Kačjak is rated as good and Voz is rated as poor.

The offer of additionalcontents is rated 1 to 5 and is maximized. Very poor offer of contents is marked with rating one and very high offer with rating five. Location Rab is rated very high, Voz is rated very weak and Kačjak is ratedweak.

There are two environmental factors: ecological value of microlocation and quality of the sea. Special attention is given to the ecological factors because today the issue of environmental protection is of utmost importance in investment projects and is the basis for making a positive or negative decision [8]. The criterion is rated through four ratings, rating one is less important and rating four extremely important. Ecological value of microlocations include the appearance of the area where port will be built and its unification with the visual quality of space, marine and land communities, and the overall aesthetic appearance of the site. When deciding on a visit to a destination, the aforementioned ecological component is attracted to a larger number of visitors. The mentioned criterion also applies to the measures of protection, arrangement and preservation of the environment and landscape of the location. Therefore, this criterion is maximized, meaning that ecologic value of microlocation is extremely important. Location Rab is rated extremely important, and the location of Voz and Kačjak as important.

The method for testing the microbiological parameters is used for the quality assessment procedure. Microbiological indicators monitored at sea are intestinal enterococci and Escherichia coli whose limit values are prescribed in Annex I of the Sea Quality Regulation (OG 73/08). The water quality criterion is rated at grades
1 to 4 in a way that the rating one indicates unsatisfactory quality, and the grade 4 is the excellent quality of the sea. All three locations were rated excellent.

Socio economic factors include attractiveness of the location and the price of the boat per meter. Nautical services users are usually people from higher social levels so tourism belongs to the elite form of tourism that demands its specific requirements.

The criterion of attractiveness of the location is rated 1 to 3 , rating one indicates low attractiveness of the location, rating two medium attractiveness of the location and rating three high attractiveness of the location, the criterion is maximized. As a criterion of attractiveness of the location in this paper, attention was given to the closeness and the offer of the fish restaurants that the users of the marina especially love. Rab was rated high by the number of fish restaurants near the marina, while the location of Voz was low, and the location of Kačjak was rated as a mid-grade.

The criterion the price of the boat per meter was rated to 1 to 3 and was minimized. Each of observed locations differsdepending on the lenght of the vesselentering the marina. Accordingly, ratings were awarded as rating one for low cost (up to $34 \mathrm{kn}$ per meter), two for medium (up to $38 \mathrm{kn}$ per meter) and three for high price (above $38 \mathrm{kn}$ per meter) formed by the marina [6]. The daily price of the boat per meter in marina Rab ranges from 194 kunas for 5 meter boat and up to 2329 for 25 meter long boat for the period of the April ,1 - June, 30 while for the period of July, 1-August, 31 cost more [6]. As the price of the boat per meter for locations Kačjak and Voz was taken from the nearest marina, namely marina Muroskva in Novi Vinodolski. The daily prices of the boat meter in the year 2018. ranges from $263 \mathrm{kn}$ for 8 meter long boat to $563 \mathrm{kn}$ for 15 meter long [6]. Location Rab was rated high while Kačjak and Voz were rated low.

Weight criteria are used to express the importance of the criterion or to differ the importance of several criteria with same priorities. Some of the sub-criterias as the impact of the wind, the impact of the waves, the proximity of the city cores and the price of the boat per meter are minimized that means their impact should be very weak or weak.

\section{ANALYSIS OF THE RESULTS / Analiza rezultata}

Choosing a marina location and its contents is a complex problem that requires careful consideration. Taking into

\begin{tabular}{|c|c|c|c|c|c|c|c|c|c|c|c|c|c|c|}
\hline Scenario1 & The impact o... I & The impact o... s & Sea tempera... $D$ & Depth of the... S & Safety appr... N & Number of $b . . . T$ & The categori... & The proximit... & The construc... I & The offer of ... & Ecological va... & The quality $0 . .$. & Attractivene... $\mathrm{p}$ & Price of the ... \\
\hline Unit & the impact of & The impact of & 5-point & 2-pooint & 3-point & 2-pooint & categorization & 9-point & 3-point & 9-point & impact & quality & 5-point & 5-point \\
\hline Cluster/Group & 0 & 0 & 0 & O & 0 & $>$ & 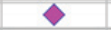 & 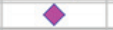 & 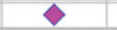 & 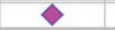 & $\square$ & $\square$ & - & - \\
\hline \multicolumn{15}{|l|}{ Preferences } \\
\hline Min/Max & $\min$ & $\min$ & $\max$ & $\max$ & $\max$ & $\max$ & $\max$ & $\min$ & $\max$ & $\max$ & $\max$ & $\max$ & $\max$ & min \\
\hline Weight & 6,00 & 7,00 & 3,00 & 7,00 & 7,00 & 3,00 & 2,00 & 2,00 & 3,00 & 2,00 & 4,00 & 4,00 & 3,00 & 4,00 \\
\hline Preference $\mathrm{Fn}$. & Usual & Usual & Usual & Level & Usual & Usual & Usual & Level & Usual & Level & Usual & Usual & Usual & Usual \\
\hline Thresholds & absolute & absolute & absolute & absolute & absolute & absolute & absolute & absolute & absolute & absolute & absolute & absolute & absolute & absolute \\
\hline -Q: Indifference & $\mathrm{n} / \mathrm{a}$ & $\mathrm{n} / \mathrm{a}$ & $n / \mathrm{a}$ & 1,00 & n/a & $\mathrm{n} / \mathrm{a}$ & $n / a$ & 1,00 & $\mathrm{n} / \mathrm{a}$ & 1,00 & $n / \mathrm{a}$ & $\mathrm{n} / \mathrm{a}$ & $\mathrm{n} / \mathrm{a}$ & $n / a$ \\
\hline -P: Preference & $\mathrm{n} / \mathrm{a}$ & $\mathrm{n} / \mathrm{a}$ & $\mathrm{n} / \mathrm{a}$ & 2,00 & $n / a$ & $n / a$ & $n / a$ & 2,00 & $\mathrm{n} / \mathrm{a}$ & 2,00 & $n / a$ & $n / a$ & $\mathrm{n} / \mathrm{a}$ & $\mathrm{n} / \mathrm{a}$ \\
\hline -S: Gaussian & $\mathrm{n} / \mathrm{a}$ & $\mathrm{n} / \mathrm{a}$ & $\mathrm{n} / \mathrm{a}$ & $n / a$ & n/a & $\mathrm{n} / \mathrm{a}$ & $n / a$ & $n / a$ & $\mathrm{n} / \mathrm{a}$ & $n / a$ & $n / a$ & $n / a$ & $n / a$ & $\mathrm{n} / \mathrm{a}$ \\
\hline \multicolumn{15}{|l|}{ Statistics } \\
\hline Minimum & 2,00 & 2,00 & 3,00 & 1,00 & 2,00 & 2,00 & 1,00 & 4,00 & 1,00 & 1,00 & 3,00 & 4,00 & 1,00 & 1,00 \\
\hline Maximum & 3,00 & 3,00 & 3,00 & 2,00 & 3,00 & 2,00 & 3,00 & 5,00 & 3,00 & 5,00 & 4,00 & 4,00 & 3,00 & 3,00 \\
\hline Average & 2,67 & 2,33 & 3,00 & 1,67 & 2,33 & 2,00 & 1,67 & 4,33 & 2,00 & 2,67 & 3,33 & 4,00 & 2,00 & 1,67 \\
\hline Standard Dev. & 0,47 & 0,47 & 0,00 & 0,47 & 0,47 & 0,00 & 0,94 & 0,47 & 0,82 & 1,70 & 0,47 & 0,00 & 0,82 & 0,94 \\
\hline \multicolumn{15}{|l|}{ Evaluations } \\
\hline Rab & Moderately & Slighty wavy & High & Sufficient & Idealy & Sufficient & Four anchors & Very high & Ideally & Very high & Extremely & Excellent & High & High \\
\hline Voz, Krk & Weak & Slightly wavy & High & Sufficient & Good & Sufficient & Two anchors & High & Bad & Very weak & Important & Excellent & Low & Low \\
\hline Kacjak & Moderately & Wavy & High & Insufficient & Good & Sufficient & Two anchors & High & Good & Weak & Important & Excellent & Medium & Low \\
\hline
\end{tabular}

Figure 3 View data

Slika 3. Prikaz podataka

Source: Created by the authors using the Visual PROMETHEE software 
consideration the Spatial plan of the Primorsko-goranska County, three locations were taken as an example. These are: location 1 - Rab, location 2 - Voz (Krk), location 3 - Kačjak (Dramalj). Each of the selected locations has its own features that need to be considered in order to determine criteria weigh. Evaluation of locations was based on various studies on individual locations. For the analysis 5 criteria and 14 subcriteria were taken and for each criterion the scoring scale was defined. The layout of the spreadsheet is shown in Figure 3.

The analysis of the result can be displayed by several different methods. The first method is PROMETHEE II graph Complete Rankings. PROMETHEE II Complete Ranking provides graphical display and makes it easier to understand the results. It is understood from Figure 4 that the maximum value of 0.3246 is achieved by location Rab which is positioned in the positive part of the chart, and is labeled green. In the negative part of the graph are the other two locations, Voz, Krk with -0.0526 , and Kačjak with -0.2895 as the worst-positioned location and are in the red position of the chart. From this it can be concluded that the location Rab is the most ideal because is closest to value 1 .

In the PROMETHEE Rainbow mode, all locations and criteria are evaluated in such a way that criteria for each location that are positively assessed are shown in the upper part of the view and criteria that are negatively rated in the lower part of the display. Figure 5 shows that Rab has the highest number of positively rated criteria compared to the other two locations. Its positive aspects are safety of approach, ecological value of micro-location, the impact of the wave, the construction of the infrastructure, attractiveness of the location, the categorization of marina, the offer of additional contents, the proximity of the city core, sea temperature, depth of sea, number of berths and sea quality. The negative side is the impact of wind and the price of the boat per meter.

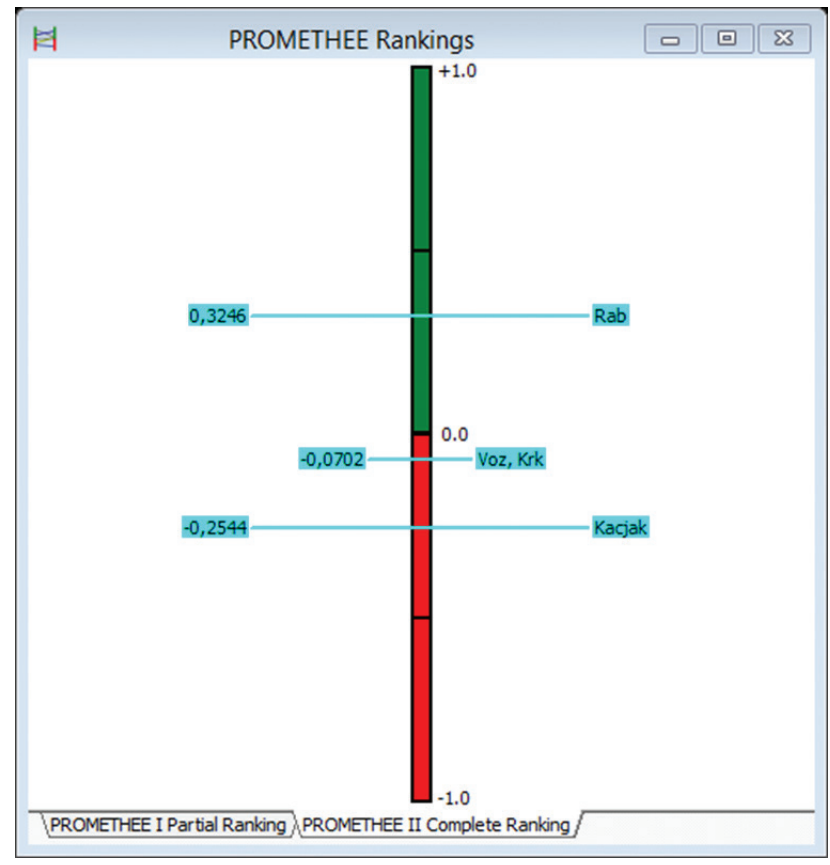

Figure 4 PROMETHEE Complete Ranking

Slika 4. Rangiranje rezultata dobivenih Promethee metodom Source: Created by authors using the Visual PROMETHEE software

PROMETHEE Flow Table provides a view of Phi, Phi + and Phi - values or sequence of actions according to the function of the preferences. It is based on the PROMETHEE II Complete Ranking. Figure 6 presents the results obtained using PROMETHEE Flow Table.

The results obtained and presented by using PROMETHEE Flow Table indicates that location Rab is the best rated location for the construction of the marina, because of the value of

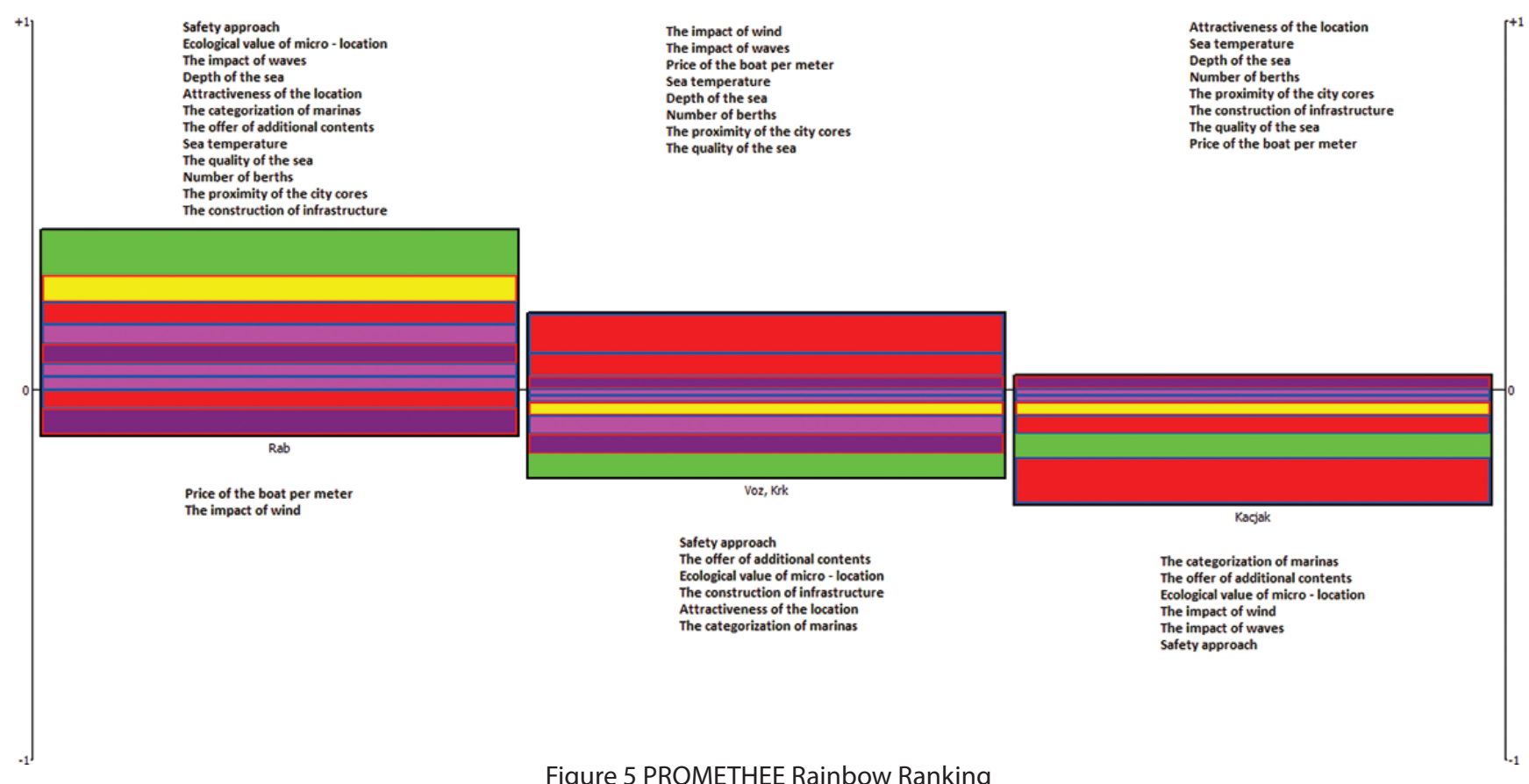

Figure 5 PROMETHEE Rainbow Ranking

Slika 5. Prikaz najbolje ocijenjenih podkriterija za lokacije Rab, Voz i Kačjak

Source: Created by authors using the Visual PROMETHEE software 


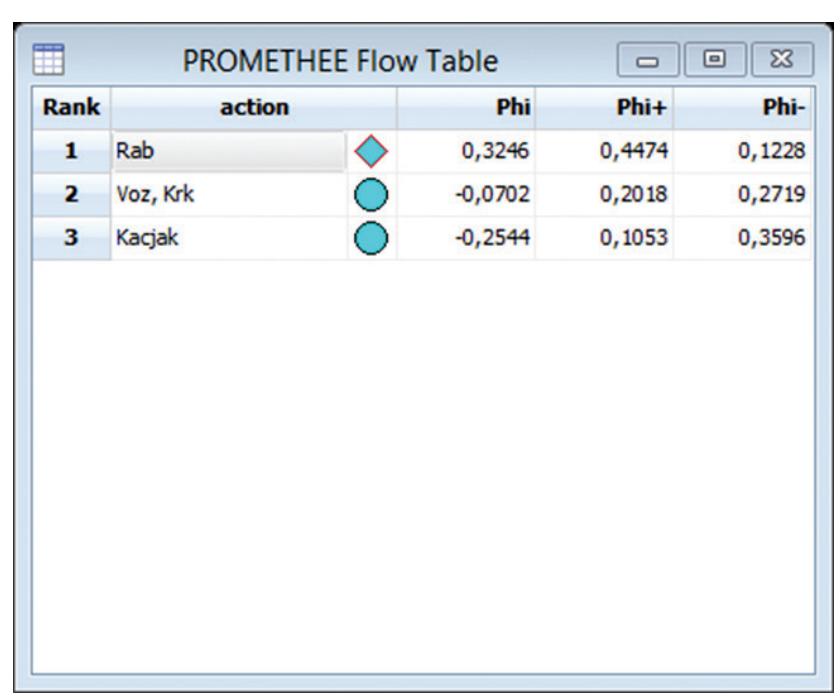

Figure 6 PROMETHEE Flow Table

Slika 6. Prikaz rangiranja rezultata na osnovi neto vrijednosti Phi Source: Created by authors using the Visual PROMETHEE software

the neto flow of 0.3246 which is the result neares to 1 and is considered as the most appropriate location. Locations Voz and Kačjak have negative value of the neto flow, for location Voz it amounts -0.0702 and for Kačjak -0.2544 .

\section{CONCLUSION / Zaključak}

The results of this research are based on Visual Promethee software support and opinion and interviews with the group of experts.The research was conducted based on five predefined core criteria and fourteen subcriteria using Promethee and Gaia method. Different weight coefficients for each criterion and their importance in relation to others were determined, resulting in a positive or negative estimate of the overall rank of analyzed sites. According to the results, existing $\mathrm{ACl}$ marina Rab has proven to be the most suitable location for further development. ACI marina Rab is potential because of its location, proximity to additional contents, sea depths and others, but the negative side is the influence of wind and the cost of berths.
That's why this location has room for upgrading, which would make it much more attractive and appealing to yachtsmen. Another rated location is Voz, suitable for the construction of a nautical port for natural factors such as the influence of wind and waves and nautical as the depth of the sea. The third location Kačjak was negatively evaluated by natural factors such as the influence of waves and winds, but it has been positively assessed by the fact that the depth of the sea and the socioeconomic attractiveness of the location makes it more attractive for tourists. Although these sites are not suited to some criteria, they have room for development from the very beginning. Such a development of nautical ports would bring new jobs, a greater number of tourists, hence higher incomes.

\section{REFERENCE / Literatura}

[1] Badurina,T. P., Dundović, Č., Grubišić, N. (2016) Selection of suitable locations for nautical tourism ports in the Ličko-senjska County, Pomorski zbornik, Vol.52, No.1, pp.133-149.

[2] https://meteo.hr

[3] Državni zavod za statistiku Republike Hrvatske, Nautički turizam, Kapaciteti i poslovanje luka nautičkog turizma u 2017., Zagreb, 2018.

[4] Elaborat zaštite okoliša u postupku ocjene o potrebi procjene utjecaja zahvata na okoliš, Rekonstrukcija i dogradnja ACI marine Rab, Institut IGH, Zavod za Hidrotehniku, Ekologiju i zaštitu okoliša, Zagreb, 2017.

[5] https://adriatic-expert.hr

[6] https://hhi.hr

[7] https://marinebook.hr

[8] Kovačić, M., Dundović, Č., (2012) Planiranje i projektiranje luka nautičkog turizma", Sveučilište u Rijeci, Pomorski fakultet u Rijeci, Rijeka.

[9] Mogućnosti razvoja luka nautičkog turizma na području Primorsko-goranske županije", Hrvatski hidrografski institut, 2012.

[10] Pravilnik o razvrstavanju i kategorizaciji luka nautičkog turizma, Narodne novine, br. 72/08

[11] Prostorni plan Primorsko-goranske županije, JU Zavod za prostorno uređenje Primorsko-goranske županije, 2012.

[12] Regulation on the quality bathing water (Official Gazette 73/08)

[13] Strategija razvoja nautičkog turizma Republike Hrvatske za razdoblje 2009. $-2019$.

[14] Studija o ujecaju na okoliš, Izmjena zahvata prihvatnog terminala za UPP na otoku Krku uvođenjem faze plutajućeg terminala za prihvat, skladištenje i uplinavanje UPP-a, EKONERG - Institut za energetiku i zaštitu okoliša, Zagreb, 2018.

[15] Šantić, L., Maglić, L., Vilke S. (2012) Ocjena postojećeg stanja i razvojni planovi luka nautičkog turizma Primorsko-goranske županije, Suvremeni promet, Vol.32, pp. 395-399. 